\title{
Gentamicin as a bactericidal agent in virological tissue cultures
}

\author{
DAVID P. CASEMORE \\ From the Department of Virology, Public Health Laboratory, General Hospital, Middlesbrough
}

SYNOPSIS For use in virological tissue culture work, gentamicin is more convenient than penicillin + streptomycin. It is bactericidal for a wider range of organisms, may be used at only half the concentration needed for penicillin and streptomycin, does not apparently interfere with growth of tissue cultures and viruses, remains active at $37^{\circ} \mathrm{C}$., and, most remarkable of all, it is stable at autoclave temperatures and so can be put into media before sterilization, thus lessening the number of additions to the sterilized medium. Gentamicin is now in routine use in this laboratory.

With the antibiotics currently employed in virology it is possible to eliminate most bacteria, natural flora or contaminants, in specimens cultured to isolate viruses and in tissues processed for culturing viruses. However, the specimens and tissues often contain bacteria resistant to these antibiotics. This difficulty is, to some extent, overcome by using a mixture of antibiotics, for example, penicillin + streptomycin, and sometimes also polymyxin or neomycin. Some of these are not heat-stable and so must be added aseptically after sterilization of the main medium; some lose their potency during incubation at $37^{\circ} \mathrm{C}$. It would therefore be advantageous to have an antibiotic with a wide enough range of activity to be used alone, and heat-stable so that it could be incorporated in the medium before sterilization and would maintain its potency at incubation temperatures. The properties of gentamicin suggested that it might meet these requirements.

Gentamicin is a broad-spectrum antibiotic, related chemically to the streptomycin group, active against Gram-positive and Gram-negative bacteria and having a remarkable degree of efficacy against Proteus and Pseudomonas species, but not active against fungi (Rosselet, Marquez, Meseck, Murawski, Hamdan, Joyner, Schmidt, Migliore, and Herzog, 1963; Barber and Waterworth, 1966). It is stable over a wide range of temperature, which permits autoclaving (Taplin, 1965). However, it seemed wise to investigate whether gentamicin's known bactericidal action was affected by the use of a complex medium as solvent and by the $p \mathrm{H}$ change from tissue metabolism, whether it had any effect on tissue cultures and on virus particles, and how it performed in routine use.

Received for publication 21 November 1966.

\section{METHODS AND RESULTS}

BACTERICIDAL ACTION From the sulphate of gentamicin, with a potency of $657 \mu \mathrm{g} . / \mathrm{mg}$., a primary dilution was made in Hanks' balanced salt solution and was autoclaved at $15 \mathrm{lb}$./in. ${ }^{2}$ for 15 minutes. Dilutions were then made to give a range from far in excess of published bactericidal concentrations to below the minimum inhibitory levels for the test organisms ${ }^{1}$. The final dilutions gave halving concentrations of gentamicin from $1,000 \mu \mathrm{g} . / \mathrm{ml}$. to $2 \mu \mathrm{g} . / \mathrm{ml}$. Aliquots of each dilution were distributed into a row of empty tubes, and into rows of tubes containing established confluent monolayers of human amnion, and Rhesus-monkey kidney cells, both washed with Hanks' balanced salt solution to remove the residue of medium containing penicillin and streptomycin.

The test organisms, Pseudomonas aeruginosa, Proteus sp., and Streptococcus faecalis, were chosen because they showed most resistance in published reports and because they cause difficulty in routine diagnostic virology, being often resistant to the antibiotics used. Each tube was seeded with all three organisms, the inoculum being one 윽 drop of a $1: 50$ dilution of an overnight broth culture. $D$ The tubes were sealed with rubber bungs, incubated at $37^{\circ} \mathrm{C}$., and examined daily for 10 days. Bacterial inhibition was indicated by clarity of the medium and $\sigma$ absence of excessive acidification; bactericidal action was $\mathrm{N}$ indicated by sterility of subcultures in nutrient broth.

The result was identical both in the presence and absence of tissue cells; gentamicin was bactericidal ${ }_{\infty}$ for all the test organisms at concentrations of $\frac{\mathscr{D}}{\mathscr{D}}$ 31 to $62 \mu \mathrm{g}$. $/ \mathrm{ml}$.

CYTOTOXIC EFFECT ON ACTIVELY MULTIPLYING CELLS Rhesus-monkey kidney, HeLa, and human amnion cells $\frac{\mathrm{D}}{\mathbb{D}}$

${ }^{1}$ The diluent was a complete tissue-culture medium of about neutral $\frac{\overparen{D}}{\mathrm{Q}}$ pH and physiologically normal, thus: Hanks' balanced salt solution $\varrho$ $86 \mathrm{ml} ., 5 \%$ lactalbumin-hydrolysate solution $5 \mathrm{ml}$., calf serum $5 \mathrm{ml}$., $5 \%$ sodium-bicarbonate/phenol-red solution $3 \mathrm{ml}$., amphotericin B $(5,000 \mu \mathrm{g} . / \mathrm{ml}$. $) 1 \mathrm{ml}$. 
were processed by the usual methods, but with gentamicin $(50 \mu \mathrm{g} . / \mathrm{ml}$.) instead of penicillin and streptomycin. As controls, some of the same cells were grown in medium containing penicillin and streptomycin (100 units and $\mu \mathrm{g} . / \mathrm{ml}$. respectively) as usual. These tubes were not inoculated with bacteria but were incubated at $37^{\circ} \mathrm{C}$. and examined microscopically each day up to 10 days, for toxic changes in the cells.

In all except one case, good results were obtained, test cells comparing well with those grown in normal medium. In the one exception, contamination proved overwhelming; this was a tissue culture of human amnion cells, obtained from a placenta delivered some hours before arrival at the laboratory. The organism was Achromobacter sp. which was resistant to the concentrations of gentamicin used and to penicillin and streptomycin in the usual concentrations.

CYTOTOXIC EFFECT ON ESTABLISHED CELL MONOLAYERS Aliquots of the concentrations used in the bactericidal test were distributed into tubes of human amnion and Rhesus-monkey kidney cells; a control row contained penicillin and streptomycin.

Some of the cells began to deteriorate towards the end of the 10 days, but there was no visible difference between the test and control cells.

EFFECT ON VIRUSES From stock suspensions of polio virus and ECHO virus, dilutions containing 100 tissue culture infective doses $s_{50}$ were treated with $2,000 \mu \mathrm{g} . / \mathrm{ml}$. of gentamicin for $\mathbf{3 0}$ minutes at room temperature, and were then inoculated into susceptible tissue cultures, previously maintained in Hanks' medium containing gentamicin $50 \mu \mathrm{g} . / \mathrm{ml}$. These, and control cultures without gentamicin, were incubated at $37^{\circ} \mathrm{C}$. and examined daily. Polio virus and ECHO virus are relatively stable but labile viruses were not available at the time of the test.

Cytopathic effects developed and progressed to complete destruction of the cell monolayers. There was no apparent difference, in type and rate of cell degeneration, between test and control cultures.

ROUTINE USE Using the results of the first tests as a guide, gentamicin was put into routine use in place of penicillin + streptomycin. The stock solution containing $2,000 \mu \mathrm{g} . / \mathrm{ml}$. in distilled water was autoclaved then stored at $4^{\circ} \mathrm{C}$. Whenever gentamicin was added to culture media, this was done in bulk before autoclaving and distribution.

Specimens needing bactericidal treatment before inoculation were treated in the usual way but with gentamicin $100 \mu \mathrm{g} . / \mathrm{ml}$. instead of penicillin + streptomycin $(100 \mu \mathrm{g} . / \mathrm{ml}$. of each). Tissue culture media contained gentamicin $50 \mu \mathrm{g} . / \mathrm{ml}$.

The results were generally good, with only occasional contamination due to Candida albicans. Viruses continue to be isolated and the condition of the cells is excellent.

I am indebted to Dr. R. Blowers for suggesting this investigation and to Roussel Laboratories Limited for supplying the gentamicin sulphate.

\section{REFERENCES}

Barber, B., and Waterworth, P. M. (1966). Brit. med. J., 1, 203.

Rosselet, J. P., Marquez, J., Meseck, E., Murawski, A., Hamdan, A., Joyner, C., Schmidt, R., Migliore, D., and Herzog, H. L. (1963). Proceedings of the 3rd Interscience Conference on Antimicrobial Agents and Chemotherapy, edited by J. C. Sylvester. Amer. Soc, Microbiol, Ann, Arbor,, p. 14,

Taplin, D. (1965). J. invest. Dermatol., 45, 549. 